DOI: $10.33067 /$ SE.2.2019.1

Elisabeth Wassermann ${ }^{\star}$

\title{
The Europeanization of Holocaust and World War II Memory in Poland - General Remarks ${ }^{1}$
}

\begin{abstract}
The article presents a summary of the reflections and research of the author (and the wider research team) on the Europeanization of heritage and memory in Holocaust and World War II museums, exhibitions and educational projects in Poland and gives a theoretical overview on the issue. In how far does the Polish way of commemoration reflect the postulates of academic research in this field? Currently in Europe, the trend in historical museums shifts from the sheer presentation of the past towards a more open format, including references to human rights, tolerance and non-discrimination. Furthermore, European museology develops towards being a platform of democratic discussion and the negotiation of meanings. What can be the potential role of Polish Holocaust and World War II museums? And how are these postulates in practice realized in cultural institutions and museums dealing with one of the greatest disasters in modern history? The research sample included the Auschwitz-Birkenau State Museum, the State Museum at Majdanek, the Home Army Museum in Kraków, the Ulma Family Museum of Poles Saving Jews in World War II in Markowa and a number of other institutions in Poland.
\end{abstract}

Key words: Europeanization, Heritage, Memory, War Museums, Holocaust

^ Elisabeth Wassermann - Jagiellonian University, e-mail: el.wassermann@gmail. com, ORCID: 0000-0001-9640-2765.

1 The article is a result of the project "The Europeanization of realms of memory and the invention of a common European heritage" (2013-2019) which was funded by the National Science Centre on the basis of allocation decision DEC-2013/08/M/HS6/00041. 
In the current context of euro-scepticism and nationalist tendencies in a number of EU member states, the question of Europeanization of memory and heritage might be considered a difficult and even provocative matter. Currently the political trend goes, especially in the Visegrad countries, rather towards a strong national identity and a clear distinction between "us, the nation" and "them, the EU" as a foreign Other with a limited intersection of mainly economic matters. On the other hand, European societies are characterized by a huge diversity and the "presence of complementary or alternative heritages and memories", ${ }^{2}$ which, amongst others, stems from the fact that the past is experienced from different points of view and with different emotions. Thus the question, if and in how far heritage presented in museums - which are significant identity-forming institutions ${ }^{3}$ - can be considered "Europeanized", is specifically important, as "social constructions of the past created from the point of view of the present are often made into a political and ideological argument". ${ }^{4}$ Thus, a common framework seems all the more to be a helpful tool.

\section{Europeanization}

For the needs of the project "The Europeanization of realms of memory", Europeanization of heritage has been defined as a three-stage "multidimensional process of transformation of European societies under the influence of European integration", including: (a) changes arising from political pressure, (b) transnational exchanges and the horizontal diffusion of ideas related to continuous encounters of people, and (c) the reshaping of collective and individual identities. ${ }^{5}$ This is a multidirectional process including all levels of selection and interpretation of heritage (local, regional, national and inter-state). In this respect, European identity, according to Mach, should rather not be seen as an aggregation of events or persons, that are per-

${ }^{2}$ K. Kowalski, B. Törnquist-Plewa, Heritage and Memory in a Changing Europe. Introductory Remarks, in: The Europeanization of Heritage and Memories in Poland and Sweden, eds. K. Kowalski, B. Törnquist-Plewa, Jagiellonian University Press, Kraków 2016, p. 15.

3 Ł. Piekarska-Duraj, Democratization as an Aspect of Heritage Europeanization. The Museum Triangle, in: The Europeanization of Heritage and Memories in Poland and Sweden, eds. K. Kowalski, B. Törnquist-Plewa, Jagiellonian University Press, Kraków 2016, p. 33 .

4 Z. Mach, Democratization and the Struggle for the Recognition of Memory and Heritage in the European Frame of Reference, in: The Europeanization of Heritage and Memories in Poland and Sweden, eds. K. Kowalski, B. Törnquist-Plewa, Jagiellonian University Press, Kraków 2016, p. 266.

5 K. Kowalski, B. Törnquist-Plewa, op. cit., pp. 21-22. 
ceived as European, but as a "frame of reference [and] platform of dialogue and negotiation", ${ }^{6}$ where different regional and national interpretations and viewpoints may be exchanged and discussed. And this is where museums and NGOs come into the picture. Potentially, they can play a meaningful role as democratic platforms, where meanings can be negotiated. ${ }^{7}$ Such institutions, again, potentially, "are much more than custodians of the past: they also should be seen as interpreters who want to have their say when various identities get constructed". ${ }^{8}$ Museums therefore support the formation of identities and are thus definitely relevant in the context of Europeanization. Thus, the question arises, how institutions like museums, which transmit knowledge, viewpoints and (in many cases) values, present Europe's fundamental ideas: human rights, the rule of law, tolerance, democracy and pluralism. Europeanization according to this concept can take place both as top-down (politics of memory conducted by states and state-controlled institutions) and bottom-up initiatives (local or regional institutions which are not state-own or controlled). ${ }^{9}$

\section{The Potential Role of Holocaust and World War II Museums in Poland in the Europeanization Process}

Having said this, the significance of Holocaust and World War II museums in this respect becomes clear: after all, they tackle a very sensitive and, despite the huge time distance to the events in question, very meaningful issue. As Aline Sierp notes, still today "the divergent interpretations of this particular period in history continue to play a fundamental role in all European countries when discussing the basic ideas and values that should guide contemporary politics and society". ${ }^{10}$ Other scholars have called the Holocaust one of "Europe's founding myths" (Leggewie) ${ }^{11}$ and "the paradigmatic liéu de memoire of Europe" (Diner). ${ }^{12}$ Thus, as Leggewie pledges, the reconciliation of competing memories of the Holocaust is a very important challenge for what is meant to be a European memory. ${ }^{13}$ Although a strictly common memory with clear-cut contents is

6 Z. Mach, op. cit., p. 266.

7 Ł. Piekarska-Duraj, op. cit., p. 35.

8 Ł. Piekarska-Duraj, B. Törnquist-Plewa, Europeanization in Regional Museums? Examples from Sweden and Poland, "Politeja", no. 52(1)/2018, p. 26.

9 Ibidem, p. 22.

10 A. Sierp, History, Memory, and Trans-European Identity. Unifying Divisions, New York-London 2014, p. 2-2.

11 C. Leggewie, Seven Circles of European Memory, "Eurozine" 2010.

12 D. Diner, Gegenläufige Gedächtnisse. Über Geltung und Wirkung des Holocaust, Vandenhoeck \& Ruprecht, Göttingen 2007, p. 39.

${ }^{13}$ C. Leggewie, op. cit. 
neither reasonably achievable nor necessarily desired, ${ }^{14}$ scholars agree on the tremendous importance of Holocaust memory in contemporary Europe. Since the growing acknowledgment of historical trauma in European culture in the 1980s and 1990s, as Aleida Assmann writes, victim perspectives are more and more integrated into the collective identity forming process. ${ }^{15}$ Although national Holocaust commemoration traditions and common narratives about World War II and the Holocaust may differ in their focus and perspective, it is necessary "that the memory of the Holocaust be developed and represented in the European frame of reference, as a common European heritage and the commemoration of the darkest moment in a common European history". ${ }^{16}$ As the Holocaust was part of World War II and would be unthinkable in peace times, the narrative of World War II as a whole cannot be omitted in this context. In this regard, Poland is a very interesting, if not the most interesting,case in Europe. All the major death camps run by the Nazi German authorities during World War II were situated on German-occupied Polish soil. Thus, the Polish gentile population was inevitably a close eye-witness of the mass murder of the European Jewry. Over $90 \%$ of the pre-war Polish Jews perished during the Holocaust, leaving post-war communist Poland an ethnically almost entirely homogenous state.

Overall, Poland lost more than six million of its pre-war population (ethnic Poles, Jews and other minorities with Polish citizenship). ${ }^{17}$ Since the late 1980 's, a variety of important nation-wide debates about Polish-Jewish relations during the war have occupied the Polish public discourse. These debates, with the discourse on the Jedwabne massacre in $2001^{18}$ as the most important one, have always been emotionally loaded and often full of misunderstand-

${ }^{14}$ According to Aleida Assmann, collective identities require a common goal for the future and common reference points in the past (see: A. Assmann, Europe: A Community of Memory? Twentieth Annual Lecture of the GHI, November 16, 2006, "GHI Bulletin", no. 40/Spring 2007, p. 12). This however does not impose the need to agree upon common contents.

15 Ibidem, pp. 11-12.

16 Z. Mach, Some Remarks on Memory and Heritage in Europe, "Politeja", no. 1(52)/2018, p. 192.

17 N. Davies, Heart of Europe. The Past in Poland's present, Oxford University Press, New York 2001, p. 55.

18 The debate had been caused by the publication of J.T. Gross' book Neighbours. The Destruction of the Jewish Community in Jedwabne, Poland, Princeton 2001, where the author writes about the responsibility of the local Polish townspeople of Jedwabne (Eastern Poland) for the mass murder of the Jewish population of the village in July 1941. Despite historical evidence for the participation of the Polish population of Jedwabne in the massacre, the public revelation of this fact was perceived as a shock in Poland. See also: B. Törnquist-Plewa, The Jedwabne Killings - A Challenge for Polish Collective Memory, in: Echoes of the Holocaust. Historical Cultures in Contemporary Europe, eds. K.-G. Karlsson, U. Zander, Lund 2003, pp. 141-171. 
ings. Since then, the role of Poles during World War II has been subject of a number of debates and is also currently a popular motive in Polish statesteered collective memory. Thus, the heroic deeds of the $6,863^{19}$ Polish Righteous among the Nations, and especially prominent figures like Jan Karski and Irena Sendler, are frequently exposed ${ }^{20}$. Furthermore, despite the growing time distance, Polish-Jewish relations during the war and the role of Polish gentile civilians during the Holocaust are still able to stir up tremendous emotions ${ }^{21}$. Apart from that, the last years have seen an intensive effort from governmental agencies and NGOs to share knowledge and teach about the Holocaust, the Righteous and World War II in Poland. ${ }^{22}$

Having said this, museums dealing with this difficult aspect of heritage are potentially meaningful agents of memory that may function as a connecting element between the past and the present, making history relevant for the present and future. In order to do so, they must offer more than just representations of the past - by transmitting timeless values and by showing behavioural patterns, they can make a point. According to Klas-Göran Karlsson's concept

19 Official number as of 1 January 2018, see: official website of Yad Vashem, https:// www.yadvashem.org/righteous/statistics.html (4.09.2018).

20 For a detailed account on the meaning of the Righteous among the Nations for Polish collective memory, see: K. Suszkiewicz, The Rise of the Righteous Among the Nations as a New Model for the Polish Hero, in: The Europeanization of Heritage and Memories in Poland and Sweden, eds. K. Kowalski, B. Törnquist-Plewa, Kraków 2016, pp. 213-240. Examples include the recently opened (in March 2016) Ulma Family Museum of Poles Saving Jews in World War II and the related press coverage, as well as the proclamation of 2014 as Jan Karski year by the Polish parliament in honour of the Polish Righteous Jan Karski, and the plan of a monument in honour of all Polish Righteous in Warsaw.

${ }^{21}$ Poland has frequently protested against the use of the historically incorrect term of 'Polish death camps' in the media or public speeches abroad. The planned, but later partly changed amendment (article 55a) to the Act on the Institute of National Remembrance, stipulated it to be a crime to "ascribe Nazi crimes to the Polish Nation or to the Polish State". In late January and February 2018, the world saw an emotional international debate, which was provoked by the speech of the Israeli ambassador to Poland Anne Azari, who uttered concern that the law would punish researchers, journalists or even Holocaust survivors telling stories on individual Polish collaborators. In June 2018, the article was amended again changing the character of such offences from criminal to civil. In February 2019, Israeli-Polish relations deteriorated again, after a number of comments of high-rank Israeli politicians accusing Poland of "imbibing antisemitism from their mothers" milk (foreign minister Katz) and revising history in their own favour (cabinet minister Bennett).

22 Some of the major initiatives include the proclamation of the Jan Karski year (2014) by the Polish parliament, the planned monument for the Polish Righteous in Warsaw, the Museum of the Second World War in Gdańsk, the Ulma Family Museum of Poles Saving Jews in World War II in Markowa, the POLIN Museum of Polish Jews in Warsaw (partly, as its subject is much broader), as well as a set of initiatives in Jan Karski's native town Łódź. 
of different uses of history, ${ }^{23}$ historical narratives can be used for contemporary aims in a variety of ways. The most important uses with regard to Europeanization are the moral and political-pedagogical uses of history. While the moral approach bases on the perceived need to stress the suffering and merits of the own group (contrasted with the foreign "Other") and is therefore a potential tool for strictly national and regional memory, the political-pedagogical use builds a bridge between past events and contemporary social problems: on the example of the past, this approach seeks to develop templates of values and behaviours to tackle problems, that arose here and now, in the present. Thus, this approach is typical for educational initiatives undertaken by Holocaust and War museums and other institution focussing on this subject area. By using the historical Nazi persecution and mass murder of Jews, contemporary issues like discrimination of ethnic or sexual minorities are tackled. This approach is clearly universal and in line with the concept of Europeanization: historical facts are used to define a common set of values (human rights, democracy, freedom, non-discrimination). ${ }^{24}$

\section{Practical Findings - Exhibitions and Educational Initiatives}

The research in the course of the project "The Europeanization of realms of memory", conducted between 2013 and 2017, encompassed both museums at former concentration camp sites, so-called "museums in situ" or "campmuseums", ${ }^{25}$ as well as other museums, institutions and initiatives in Poland,

${ }^{23}$ K.-G. Karlsson, The Holocaust as a Problem of Historical Culture, in: Echoes of the Holocaust. Historical Cultures in Contemporary Europe, eds. K.-G. Karlsson, U. Zander, Lund 2003, pp. 38-41. Karlsson identifies the following uses of history: scholarly-scientific, existential, moral, political-pedagogical and ideological.

24 Ł. Piekarska-Duraj, op. cit., p. 41.

25 See: Obóz-Muzeum. Trauma we współczesnym wystawiennictwie (Camp-museum. Trauma in Contemporary Exhibition Art), eds. M. Fabiszak, M. Owsiński, Kraków 2013. This type of museum is very specific. Apart from their main function as authentic historical sites, commemorating the events that have taken place exactly there, they are also documenting facts based on original artefacts and engage in knowledge transfer, the commemoration of all victim groups and education of the young generation [See: T. Kranz, Muzea martyrologiczne jako przestrzenie pamięci i edukacji (Martyrological Museums as Sites of Memory and Educations), in: Obóz-muzeum. Trauma we wspótczesnym wystawiennictwie (Camp-museum. Trauma in Contemporary Exhibition Art), eds. M. Fabiszak, M. Owsiński, Kraków 2013, p. 53]. Due to the international character of the Holocaust, they function as "carriers of commemoration culture" both on local and national as well as on an international level [See: T. Kranz, Krajobrazy pamięci-podmioty kultury-obiekty turystyczne - przestrzenie edukacji. O współczesnych znaczeniach muzeów w poobozowych miejscach pamięci (Landscapes of memory - cultural institutions - touristic objects 
which engage in educational activities and/or the creation and promotion of exhibitions on World War II and Holocaust related topics. ${ }^{26}$ In the next part of the article, a short summary of findings regarding elements of Europeanization in such museums and initiatives will be presented. Which tendencies can be found? Do Polish Holocaust and World War II museums focus on a clearcut top-down mainstream narrative, or do they also tackle issues like gender and ethnical or religious minority experiences during the war? Are Polish museums and institutions of this kind places of dialogue and discussion? What kind of role can and do they play in the Europeanization of heritage and which factors are decisive for the question, if commemoration is strictly oriented to the past and focussing on the own nation, or if it used as a canvas for disseminating human rights and tolerance for a better future?

\section{Exhibitions}

As part of the research, the author analysed a number of exhibitions in Polish Holocaust and World War II related museums. In the result, different approaches on the scale between national and European patterns have been identified. A good example of the broad spectrum of such approaches give the national exhibitions at the Auschwitz-Birkenau State Museum, ${ }^{27}$ which use to be created by institutions from the respective countries, in some cases in cooperation with experts and outside institutions, and always consulted with the responsible Museum department. ${ }^{28}$ Thus, the state-owned Auschwitz-Birkenau Museum allows foreign institutions from different countries to actively create contents aimed at the formation of collective memory of the victims of Auschwitz from their country. An analysis of chosen national

- educational spaces. On the contemporary significance of museums at memorial sites of former concentration and death camps), in: Muzea w poobozowych miejscach pamięci. Tożsamość, znaczenia, funkcje (Museums at memorial sites of former concentration and death camps. Identity, meanings, functions), ed. T. Kranz, Lublin 2017, p. 37].

${ }^{26}$ The overall sample included the Jan Karski Foundation in Kielce, the Marek Edelman Dialogue Center in Lodz, the Ulma Family Museum of Poles Saving Jews in World War II in Markowa, the Home Army Museum in Kraków, the Auschwitz-Birkenau State Museum, the State Museum at Majdanek and the Museum of the Former Kulmhof Death Camp in Chelmno on Ner.

27 See the full Article: E. Büttner, Europeanization at the Memorial Sites of Former Nazi Concentration Camps in Poland. The Cases of Auschwitz, Majdanek and Kulmhof, in:The Europeanization of Heritage and Memories in Poland and Sweden, eds. K. Kowalski, B. Törnquist-Plewa, Krakow 2016, pp. 249-253. The following paragraphed is based on those findings.

28 The museum holds 11 national exhibitions: Roma, Russia, Poland, Slovakia, Czech Republic, Austria (under renovation), Hungary, Belgium, France, Netherlands, Shoah (Israel). See: http://auschwitz.org/en/visiting/national-exhibitions/ (10.03.2018). 
exhibitions ${ }^{29}$ has illustrated a change over time, as I have argued: the shift goes from an unambiguous top-down approach, aimed at the transfer of facts, to forms of participation, openness for debate and a focus on individual fates of different victim groups. ${ }^{30}$ An example for an old exhibition with a traditional, number-based, collectivized approach and a clear-cut topdown narrative is the Polish exhibition The Struggle and Martyrdom of the Polish Nation 1939-1945 from 1985 (amended in the 1990s). It gives a bundled overview over the German invasion of Poland and the suffering of the nations in occupied Poland, with Polish gentile Auschwitz prisoners as one of the victim groups. Instead of Auschwitz, the suffering and martyrdom of the Polish nation is in the focus of the exhibition. As it concentrates on facts and numbers, complemented by drastic pictures of mass graves and anonymous piles of corpses, it does not leave space for discussion or participation on the side of the visitors.

The newer exhibitions, and especially the French national exhibition from 2005 , however tend to leave room for discussion about contemporary patterns of persecution and discrimination, and encourage visitors to take their own stance on the issue presented. In opposite to the Polish exhibition, the French one presents the whole range of attitudes towards the persecution of Jews within France under German occupation: from aid, over indifference, to cases of active collaboration and treachery. Furthermore, visitors find a number of personal stories of French Auschwitz prisoners (Jewish and non-Jewish), which they may choose to track throughout all the exhibition rooms.

A similar approach can also be traced in the exhibition The Prisoners of Majdanek at the State Museum at Majdanek (opened in 2014 on the occasion of the $70^{\text {th }}$ anniversary of the camp's liberation). Located in one of the preserved prisoners barracks, it supplements the much older main exhibition, which focusses on the general history of the camp and the living conditions of the prisoners. Also here, individual fates of prisoners of different national and ethnic origin, age, gender and social positions, are presented. Visitors may choose to follow chosen individuals' stories while making their way through the exhibition space. The exhibition includes a large variety of archive materials and artefacts, but also multimedia devices with photographs and other additional information. Thus, the presented perspective is inclusive, wide and universal - depending on the visitors' needs and interests, different meanings can be created and negotiated.

29 The Polish, Sinti and Roma, and French exhibitions have been chosen based on an analysis of all 10 national exhibitions at the State Museum Auschwitz-Birkenau (visit in October 2015).

${ }^{30}$ E. Büttner, op. cit., p. 259. 
A different, much more conservative approach was found in the Home Army Museum in Kraków, a local self-government unit of the city and the Malopolska voivodship. The permanent exhibition of the museum focusses on the history of the armed resistance in German-occupied Poland and the military merits of the Polish Home Army. As an in-depth analysis has shown, the main exhibition is "a place where moral questions are asked, where history is rather made than shown, and faults in history tend to be omitted and withheld from the narrative". ${ }^{31}$ Poland is depicted as a suffering, but bravely struggling country and one of the main victims of World War II, and this picture is used as a canvas for the myth-building of the Home Army as an army of (exclusively) brave freedom fighters. Other European countries are mentioned in the context of the lack of support (i.e. France and Great Britain in 1939) or as perpetrators (Nazi Germany). Europe as a whole is only marginally mentioned in the final part of the exhibition only and put in a Christian context. Thus, as the analysis shows, the role of Europe as depicted in the museum is perfectly in line with the current euro-sceptic government in Poland, which sees Europe as a difficult partner of a strong and proud Polish national state, that seeks to transfer as little decision-making power as possible to Brussels.

A mixed approach characterized the main exhibition of the Ulma Family ${ }^{32}$ Museum of Poles Saving Jews in World War II in Markowa, which is dedicated to Poles from the Podkarpacie region, who provided aid and rescued Jews under German occupation. ${ }^{33}$ The museum has been opened in March 2016 as a local Polish commemoration initiative. ${ }^{34}$ Its main exhibition gives a short overview over the coexistence of Jews and Poles in the Podkarpackie region before 1939, tackles then the persecution of Jews by the Germans and the cases of aid-provision by local Poles, with a special focus on the history of the

${ }^{31}$ E. Wassermann, Us and Them. The Other in the Home Army Museum in Kraków, in: Narrating Otherness in Poland and Sweden. European Heritage as a Discourse of Inclusion and Exclusion, eds. K. Kowalski, Ł. Piekarska-Duraj, B. Törnquist-Plewa, Peter Lang, New York-Oxford-Warszawa-Wien 2019, pp. 275-300.

32 The Ulma Family was a Polish peasant family with six children, that hid a group of 8 Jews in their house during World War II. The entire family together with all hidden Jews was killed by German police forces, assisted by several Polish Navy-Blue police men on 29 March 1944. Wiktoria and Józef Ulma were posthumously awarded the title Righteous among the Nations in 1995. Since 2003, the beatification process of the entire Ulma Family is under way.

33 The part on the Ulma Family Museum bases on my own research published in the article E. Büttner, The Polish Discourse about the Righteous among the Nations. Between Commemoration, Education and Justification?, "Politeja”, no. 1(52)/2018, pp. 125-144.

${ }^{34}$ Interview with Bożena Knocbęda, employee of the Castle Museum in Łańcut and coordinator of the Markowa museum project, 10 April 2015. As she pointed out, the initiative to build the museum dates stem from members of the local municipal council and the marshal of the Podkarpackie voivodship. 
Ulma Family, and ends with a short overview of events in the post-war period. As the museum is a local bottom-up project, the narrative of the permanent exhibition is strictly concentrated on the rescuers and their aid in the Podkarpackie region. Thus, problems like cases of denunciation of rescuing families to the Gestapo by their Polish fellow townspeople and pre-war anti-Semitism are not explicitly tackled. Nevertheless, the exhibition does contain references to this problem in short film interviews with contemporary witnesses, which the visitor can choose to watch. Here, the speakers inform about acts of hostility they experienced when providing aid to persecuted Jewish individuals. Furthermore, the exhibition mentions that only a small part of Polish society actively provided aid, while the majority did not, as the Germans had introduced the death penalty for all aid providers.

By tackling difficult issues, the museum potentially provokes the audience to ask timeless, always actual moral questions, of how oneself would have reacted to the suffering of neighbours in times of atrocity and persecution. Furthermore, the multimedia installations invite visitors to watch and listen to personal stories of locals and thus to construct their own narrative of the past.

An example for an open and universal approach to history is the exhibition Karski - Don't let the world forget of the National Center of Culture, presented in the Marek Edelman Dialogue Center in Lodz (2014). ${ }^{35}$ The rich and multi-faceted exhibition contains three different main plots: (i) biographical information about Jan Karski ${ }^{36}$ (i.e. historical facts, quotes portraying his feelings, opinions and personal interpretation of important events of his life); (ii) matters of universal meaning, i.e. anti-Semitism in interwar Poland and the importance of individual attitudes in the face of evil); and (iii) reactions from the outside world to the Holocaust. The exhibition is a remarkable example of a multi-faceted and unbiased approach to commemoration-it does not use the discourse of the Righteous among the Nations in order to defend Polish patriotic honour and to stifle discussions about cases of collaboration and indifference in Polish society towards persecuted Jews. An example that underlines this approach can be found in the foreword of the exhibition catalogue: "Who was Jan Karski and who is he for us nowadays? A hero? A witness of the biggest crime in human history? Or maybe - a reproach for our

35 Virtual visit of the exhibition accessible under: https://www.centrumdialogu. com/wydarzenia/1494-wirtualny-spacer-po-wystawie-karski-nie-da-wiatu-zapomnieq (24.03.2019).

36 Jan Karski (born 1914) was a Polish soldier and courier of the Polish governmentin-exile during World War II. In 1982, he received the medal Righteous among the Nations for his attempts to inform Jewish community leaders and heads of states and governments abroad about the mass murder of Polish Jews by the Nazis. 
conscience?". ${ }^{37}$ Here, Karski is portrayed as a reproach for humanity in general, then and nowadays." That the exhibition goes further than just PolishJewish relations, becomes also evident from a quote of Karski at the end of the presented contents: "The second original sin was committed by man as a consequence of self-imposed ignorance, insensivity, selfishness, hypocrisy or soulless rationalization. This sin will persecute humankind until the end of the world. It persecutes me personally. And I want it to do so". ${ }^{38}$ As it is obvious, the message of the Karski exhibition is timeless, always actual and not restricted to one nation. It invites visitors to examine their own conscience and obliges visitors to remember.

\section{Education}

Apart from exhibitions, all visited institutions also engaged in a variety of educational initiatives, which aim not only at teaching facts about the Holocaust, but also at the dissemination of more universal values. The following sub-chapter summarizes just a few of them. One of the most known is the International Center for Education about Auschwitz and the Holocaust (ICEAH) at the State-Museum Auschwitz-Birkenau. According to the official website, besides teaching historical facts on the mass murders committed at the Auschwitz camp site, the Center also engages in teaching human rights: "The context of Auschwitz makes it possible to take a closer look at the challenges of the modern world. What is an individual compared to authority? What are human rights? How to recognize the first symptoms of them being limited? What can a man do in the face of totalitarianism? These are just some of the questions that hundreds of thousands of people visiting the Auschwitz Memorial each year ask themselves". ${ }^{39}$ The ICEAH offers a variety of international educational projects, conferences, e-learning courses and thematic sessions. The target audience of the activities includes students, adults, staff of cultural organisations, teachers, holders of public offices and penitentiary inmates. ${ }^{40}$ In 2017, over 17000 people participated in the programs and activities of the ICEAH. ${ }^{41}$ As an example, the annual international Summer Academy - apart from the transfer of historical knowledge -always includes time for discussions on how the memory of Ausch-

${ }^{37}$ Karski. Nie dać światu zapomnieć (Karski. Don't let the World Forget), Exhibition catalogue, Łódź 2014, p. XX.

38 Ibidem, p. 147.

39 Original statement on the website of the Auschwitz-Birkenau State Museum on its website, http://auschwitz.org/en/education/iceah-general-information/ (2.09.2018).

40 Annual Museum Report of the State Museum Auschwitz-Birkenau for 2015, www. auschwitz.org (2.09.2018), p. 32.

${ }^{41}$ Annual Museum Report of the State Museum Auschwitz-Birkenau for 2017, www. auschwitz.org (2.09.2018), p. 27. 
witz ought to be used in contemporary education. ${ }^{42}$ Furthermore, the ICEAH conducts two postgraduate study programs, ${ }^{43}$ which are addressed (among others) to teachers and staff of cultural organizations "engaged in counteracting xenophobia and anti-Semitism" and aim at "developing skills to overcome prejudices and stereotypes among the youth". ${ }^{44}$

Similar motives can be traced in the educational program of the Ulma Family Museum of Poles Saving Jews in World War II, which includes a number of workshops and projects. Among the proposed 45-minute-workshops for adults and children are "Attitudes of Poles towards the doomed Jews" and "Genesis of Polish-Jewish relations in the Podkarpacie region". The contents include the complex Polish-Jewish relations and examples for attitudes of Poles facing the Holocaust. ${ }^{45}$ The wide spectrum of reactions to injustice, discrimination and persecution is also the focus of the educational project "The World of the Righteous", which the Ulma Family Museum conducts since $2016^{46}$ and which is addressed to prison inmates from the Rzeszów region. Its aim is to offer an opportunity to "verify own life choices and to develop a new value system" in order to facilitate re-adaptation after the release from prison. ${ }^{47}$ By discussing individual stories, such as the fate of the Ulma Family, who were murdered for their readiness to help, the project links the past with the present: values like helpfulness, empathy and non-discrimination. History

42 The international Summer Academy is organized annually in English and German. In 2018, the program included lectures on the history of the Auschwitz-Birkenau concentration camp complex as well as on the symbolism and meaning of the AuschwitzBirkenau memorial nowadays, the opportunities and obstacles related to teaching about the Holocaust in Poland and other countries and the lessons to be learned from Auschwitz. See: Draft program of the international summer academy Auschwitz - History, Memory and Education, available for download on the official website of the Auschwitz-Birkenau State Museum http://auschwitz.org/en/museum/news/international-summer-academy-2018call-for-participants, 1296.html (2.09.2018).

43 The first study program is entitled "Totalitarianism-Nazism-Holocaust" and focusses, among other topics, on history and the contemporary depiction of the Holocaust in art, film and literature. The second program is conducted in cooperation with the Pontificial University of John Paul II in Krakow, its main topic are Christian-Jewish and PolishJewish relations in history and nowadays. For more information, see the official website of the Auschwitz-Birkenau State Museum, http://auschwitz.org/en/education/studies/ (2.09.2018).

${ }^{44}$ See: ibidem.

45 Information from the official website of the Ulma Family Museum of Poles Saving Jews in World War II, https://muzeumulmow.pl/pl/edukacja/oferta-warsztatowa/ (5.09.2018).

${ }^{46}$ A detailed project description in Polish language can be found on the official website of the Ulma Family Museum of Poles Saving Jews in World War II, https://muzeumulmow.pl/pl/edukacja/projekty/ (5.09.2018).

47 Ibidem. 
is used as a means for education and to form the mind of participants with regard to their personal lives and choices. Thus, history is universalized and made useful for the future, according to Karlssons's concept of the politicalpedagogical use of history.

\section{Conclusion}

Is Polish Holocaust and World War II memory therefore "European", or does it at least show elements of Europeanization? Indeed, it does - albeit only on a limited scale. This conclusion becomes obvious, if one compares the analytic material of the author's study with the two main characteristics of Europeanization of heritage with regard to Holocaust museums, as defined above. Firstly, this was the question of democratization of museum approaches. Some of the analysed museums and initiatives did provide a platform for discussion and interpretation by the visitors. An example here is the Karski exhibition in Łódź), which tries to shift Jan Karski's motivations and deeds to the present, to universalize them and make them meaningful for today's audience. Leaving visitors with unanswered questions about the evil in general allows, and even provokes, discussion and individual meaning creation processes. Poland and Łódź were here simply the canvas for a story with an universal message. Also the Ulma Family Museum included such aspects, albeit less exposed, in form of short film interviews with locals. The few critical voices of Polish peasants with regards to the attitudes of society to Jews under German occupation are another example of how museum institutions can invite visitors to question mainstream narratives and make up own opinions. In contrast to this, the permanent exhibition of the Home Army Museum in Kraków is an example for a nation-centred and exclusive way of telling history. Here, the overall narrative is characterised by a classical dichotomy of "us against them". "We", the nation, includes only positive attributes. "They" (all Others) are either depicted descriptively or outmost negatively, without significant exceptions. ${ }^{48}$ Visitors thus are "told history" according to a clear-cut narrative, but they are not supposed to interpret or participate in the negotiation process of meaning ${ }^{49}$ according to the new museology approach, which expects museums to strive "for multivocality instead of constructing heritage only by recreating the official discourse of the past". ${ }^{50}$

48 Ibidem, p. 295.

49 For more information on this topic, see: V. McCall, C. Gray, Museums and the 'new museology': theory, practice and organisational change, "Museum Management and Curatorship", no. 1, vol. 29/2013, pp. 1-17.

50 Ł. Piekarska-Duraj, B. Törnquist-Plewa, Europeanization in Regional Museums? Examples from Sweden and Poland, "Politeja", no. 52(1)/2018, p. 28. 
Secondly, there is the presence and emphasis on values, that are typically considered as immanent to the European Union: human rights, tolerance, minority rights, non-discrimination rule of law, democracy and freedom. In this respect, especially educational initiatives showed progressive patterns, as i.e. a resocialization project for prison inmates at the Ulma Family Museum and summer academies at the ICEAH.

What decides about the direction a museum takes? This seems to be a complicated question. With regards to the Home Army Museum, I have identified the ownership as one of the decisive factors: as the institution was initially founded and developed by veterans of the Home Army, who wanted the museum to be a space to present their struggle for independence and show personal souvenirs (such as uniforms, weapons, documents, etc.). Thus, as I have argued, the perspective is necessarily one-sided and limited, and cannot be expected to be critical towards the mainstream narrative. This has therefore proven to be an "obvious and clear restriction for Europeanization processes". ${ }^{51}$

The analysis has shown, that where history is used in an ideological way (according to Karlsson), there is hardly space for negotiation and plurality of meanings. Where the pedagogical use of history prevailed, past events were transformed into fundamental questions and discussed with the visitors. What is visible in almost all the museums and initiatives which were part of the research sample, is the a distinct Polish narrative of World War II. From the Polish point of view, the key words are Westerplatte, Generalplan Ost, Operation Reinhard, Forced Labour, but also Home Army and Warsaw Uprising. These core elements differ sometimes diametrically from the experiences in other European countries. ${ }^{52}$ As long as the main emphasis of commemoration of an institution will be the Polish perspective only, with the sole focus on national suffering and heroism - as it seems to be especially the case since the coming into power of the conservative right-wing government in Poland in 2015 - the democratization and introduction of universal patterns seems to be an aim that is difficult to reach on a broader basis. It will thus be the task of non-government agents to propose a different approach and invite new trends and viewpoints into their initiatives.

\footnotetext{
51 E. Wassermann, op. cit., p. 296.

52 A. Sierp, op. cit., p. 2.
} 


\section{References}

Annual Museum Report of the State Museum Auschwitz-Birkenau for 2015, www.auschwitz.org.

Annual Museum Report of the State Museum Auschwitz-Birkenau for 2017, www.auschwitz.org.

Assmann A., Europe: A Community of Memory? Twentieth Annual Lecture of the GHI, November 16, 2006, "GHI Bulletin”, no. 40/Spring 2007.

Büttner E., Europeanization at the Memorial Sites of Former Nazi Concentration Camps in Poland. The Cases of Auschwitz, Majdanek and Kulmhof, in: The Europeanization of Heritage and Memories in Poland and Sweden, eds. K. Kowalski, B. Törnquist-Plewa, Jagiellonian University Press, Kraków 2016.

Büttner E., Suszkiewicz K., Remembrance Days in European Union - between Oblivion, National Manifestation and an European Narrative?, "Studia Żydowskie Almanach", no. 6/2017.

Davies N., Heart of Europe. The Past in Poland's present, Oxford University Press, New York 2001.

Diner D., Gegenläufige Gedächtnisse. Über Geltung und Wirkung des Holocaust, Vandenhoeck \& Ruprecht, Göttingen 2007.

Gross J.T., Neighbours. The Destruction of the Jewish Community in Jedwabne, Poland, Princeton, New York 2001.

Karski. Nie dać światu zapomnieć (Karski. Don't let the World Forget), Exhibition catalogue, Łódź 2014.

Karlsson K.G., The Holocaust as a Problem of Historical Culture, in: Echoes of the Holocaust. Historical Cultures in Contemporary Europe, eds. K.G. Karlsson, U. Zander, Nordic Academic Press, Lund 2003.

Kowalski K., Toernquist-Plewa B., Heritage and Memory in a Changing Europe. Introductory Remarks, in: The Europeanization of Heritage and Memories in Poland and Sweden, eds. K. Kowalski, B. Törnquist-Plewa, Jagiellonian University Press, Kraków 2016.

Kranz T., Muzea martyrologiczne jako przestrzenie pamięci i edukacji (Martyrological Museums as Sites of Memory and Educations), in: Obóz-muzeum. Trauma we współczesnym wystawiennictwie (Camp-museum. Trauma in Contemporary Exhibition Art), eds. M. Fabisiak, M. Owsiński, Universitas Kraków 2013.

Kranz T., Krajobrazy pamięci - podmioty kultury - obiekty turystyczne przestrzenie edukacji. O wspótczesnych znaczeniach muzeów w poobozowych miejscach pamięci (Landscapes of memory - cultural institutions - touristic objects - educational spaces. On the contemporary significance of museums at memorial sites of former concentration and death camps), 
in: Muzea w poobozowych miejscach pamięci. Tożsamość, znaczenia, funkcje (Museums at memorial sites of former concentration and death camps. Identity, meanings, functions), ed. T. Kranz, Państwowe Muzeum na Majdanku, Lublin 2017.

Leggewie C., Seven Circles of European Memory, "Eurozine" 2010, DOI: https://doi.org/10.1007/978-90-481-8945-8_8.

Leggewie C., Der Kampf um die europäische Erinnerung. Ein Schlachtfeld wird besichtigt (The Struggle about European Memory. A visit at the battlesite), C.H. Beck, München, 2011, DOI: https://doi. org/10.17104/9783406619960.

Mach Z., Democratization and the Struggle for the Recognition of Memory and Heritage in the European Frame of Reference, in: The Europeanization of Heritage and Memories in Poland and Sweden, eds. K. Kowalski, B. Törnquist-Plewa, Jagiellonian University Press, Kraków 2016.

Mach Z., Some Remarks on Memory and Heritage in Europe, "Politeja", no. 1(52)/2018, DOI: https://doi.org/10.12797/Politeja.15.2018.52.09.

McCall V., Gray C., Museums and the 'new museology': theory, practice and organisational change, "Museum Management and Curatorship", no. 1, vol. 29/2013, DOI: https://doi.org/10.1080/09647775.2013.869852.

Obóz-Muzeum. Trauma we wspótczesnym wystawiennictwie (Camp-museum. Trauma in Contemporary Exhibition Art), eds. M. Fabiszak, M. Owsiński, Universitas, Kraków 2013.

Piekarska-Duraj Ł., Democratization as an Aspect of Heritage Europeanization. The Museum Triangle, in: The Europeanization of Heritage and Memories in Poland and Sweden, eds. K. Kowalski, B. Törnquist-Plewa, Jagiellonian University Press, Kraków 2016.

Piekarska-Duraj Ł., Törnquist-Plewa B., Europeanization in Regional Museums? Examples from Sweden and Poland, "Politeja", no. 52 (1)/2018, DOI: https://doi.org/10.12797/Politeja.15.2018.52.03.

Sierp A., History, Memory, and Trans-European Identity. Unifying Divisions, New York-London 2014, DOI: https://doi.org/10.4324/9781315766973.

Suszkiewicz K., The Rise of the Righteous Among the Nations as a New Model for the Polish Hero, in: The Europeanization of Heritage and Memories in Poland and Sweden, eds. K. Kowalski, B. Törnquist-Plewa, Kraków 2016.

Törnquist-Plewa B., The Jedwabne Killings - A Challenge for Polish Collective Memory, in: Echoes of the Holocaust. Historical Cultures in Contemporary Europe, eds. K.-G. Karlsson, U. Zander, Nordic Academic Press, Lund 2003.

Wassermann E., The Polish Discourse about the Righteous among the Nations. Between Commemoration, Education and Justification? "Politeja" 1(52)/2018, DOI: https://doi.org/10.12797/Politeja.15.2018.52.06. 
Wassermann E., Us and Them. The Other in the Home Army Museum in Kraków, in: Narrating Otherness in Poland and Sweden. European Heritage as a Discourse of Inclusion and Exclusion, eds. K. Kowalski, Ł. Piekarska-Duraj, B. Törnquist-Plewa, Peter Lang, New York-Oxford-WarszawaWien 2019.

Ziębińska-Witek A., Miejsca Zagłady jako przestrzenie ekspozycyjne (Holocaust sites as exhibition space), in: Muzea w poobozowych miejscach pamięci. Tożsamość, znaczenia, funkcje (Museums at memorial sites of former concentration and death camps. Identity, meanings, functions), ed. T. Kranz, Państwowe Muzeum na Majdanku, Lublin 2017.

Interviews

Interview with Bożena Knocbęda, employee of the Castle Museum in Łańcut and coordinator of the Markowa museum project, 10 April 2015.

Interview with Konstanty Gebert, member of the Remembrance and Future Foundation, 28 June 2016.

\section{Websites}

https://www.yadvashem.org/righteous/statistics.html.

http://auschwitz.org/en/visiting/national-exhibitions/.

http://auschwitz.org/en/education/iceah-general-information/.

http://auschwitz.org/en/museum/news/international-summer-academy-2018call-for-participants, 1296.html.

http://auschwitz.org/en/education/studies/.

https://www.centrumdialogu.com/wydarzenia/1494-wirtualny-spacer-po-

wystawie-karski-nie-da-wiatu-zapomnieq.

https://muzeumulmow.pl/pl/edukacja/oferta-warsztatowa/.

https://muzeumulmow.pl/pl/edukacja/projekty/. 